\title{
OS DOCUMENTOS DE DIREITOS HUMANOS DO MUNDO MUÇULMANO EM PERSPECTIVA COMPARADA
}

\author{
Luana Hordones Chaves ${ }^{1}$
}

\begin{abstract}
RESUMO
Uma das questões teóricas mais importantes do debate islâmico de direitos humanos é a relação entre secularismo e direitos do homem, e a questão empírica correlata: a aplicação da xaria. Trata-se do que Enzo Pace chamou de déficit estrutural de legitimação no Islã, referindo-se às características originárias, particularmente à fusão entre as dimensões religiosa e política, como desafio à adesão ao sistema de direitos humanos da ONU. Nessa perspectiva, o presente artigo analisa documentos sobre direitos humanos produzidos no mundo muçulmano, dando maior importância àqueles produzidos em ambiente intergovernamental, uma vez que refletem as preocupações e os esforços desses governos em se inserirem na discussão dos direitos humanos.
\end{abstract}

Palavras-chave: Direitos humanos. Documentos. Islã. Xaria.

\footnotetext{
Doutoranda em Sociologia pela Universidade Federal de Minas Gerais. Brasil. luanahordones@hotmail.com
} 


\title{
THE HUMAN RIGHTS DOCUMENTS OF THE MUSLIM WORLD FROM A COMPARATIVE PERSPECTIVE
}

\begin{abstract}
One of the most important theoretical issues in the Islamic debate on human rights is the relationship between secularism and human rights and the related empirical question of the application of sharia. This issue is what Enzo Pace calls the structural deficit of legitimacy in Islam, referring to its original characteristics, particularly the fusion of religious and political dimensions, as a challenge in adhering to the United Nations (UN) human rights system. From that perspective, this article analyzes human rights documents produced in the Muslim world, attributing more importance to documents produced in intergovernmental environments because they reflect the concerns and efforts of these governments to participate in the discussion of human rights.
\end{abstract}

Keywords: Human rights. Documents. Islam. Sharia.

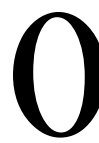

$s$ direitos humanos podem ser entendidos como um conjunto de valores consagrados em instrumentos jurídicos internacionais, e referem-se a diversas condições e possibilidades destinadas a tratar dos direitos dos homens.

Foi no contexto pós-Segunda Guerra que a proposta dos direitos humanos passou a ser discutida na Organização das Nações Unidas, a fim de se elaborar uma declaração de caráter universal acerca dos direitos do homem. Os milhões de mortes e torturas ocorridas durante a Segunda Guerra Mundial, assim como a situação dos apátridas no pós-guerra conduziram o surgimento do regime internacional de direitos humanos.

Um projeto de universalização dos direitos humanos passou a ser desenvolvido durante os anos de 1947 e 1948 pela Comissão de Direitos Humanos, criada pela Carta das Nações Unidas em 1946. A Declaração Universal de Direitos Humanos foi aprovada em 10 de dezembro de 1948 pela Resolução $n$. 217 A (III) da Assembleia Geral das Nações Unidas. A redação da Declaração foi iniciada pela Comissão de Direitos Humanos que contava, na ocasião, com representantes dos seguintes países: Bielorússia, Estados Unidos, Filipinas, União das Repúblicas Socialistas Soviéticas, França e Panamá. A aprovação do texto final contou, por sua vez, com quarenta e oito votos a favor dos então cinquenta e oito Estados-membros das Nações Unidas, não havendo, nessa ocasião, voto contra. 
Com duas ausências, foram oito os países que se abstiveram: Bielorússia, Checoslováquia, União das Repúblicas Socialistas Soviéticas, Polônia, Ucrânia, África do Sul, Iugoslávia e Arábia Saudita ${ }^{2}$ (TRINDADE, 2003). É notado, portanto, o restrito número de países que participaram tanto da elaboração, quanto da aprovação da Declaração de Direitos Humanos.

Aprovada a Declaração, no âmbito do Direito Internacional começou a ser delineado o sistema normativo internacional de proteção de direitos humanos por meio de tratados, enquanto no âmbito do Direito Constitucional ocidental a abertura ao Direito Internacional exigiu a observância de princípios materiais (isto é, de conteúdo) de política de direito internacional na elaboração do direito interno. Tendo em vista que o papel do Direito, tanto no âmbito interno, quanto na esfera internacional, é submeter as diretrizes políticas à racionalidade jurídica a fim de evitar os abusos de poder e permitir a participação dos cidadãos em suas decisões, são muitas as questões que permeiam o debate quanto à universalidade e à efetividade dos direitos humanos tais como postos pela ONU. Por isso, a questão da validade da Declaração Universal de Direitos Humanos, seja como instrumentos normativos das relações internacionais ou como linguagem do diálogo intercultural, é um tema caro dentro e fora do Ocidente. E como essa questão não é a proposta deste artigo, o que interessa dizer é que a partir desses eventos históricos, os direitos humanos se tornaram um tema de grande relevância na agenda internacional sem, todavia, se esgotar no que propõe a Declaração de 1948.

É nesse aspecto que os direitos humanos islâmicos ganham destaque para análise: a cultura islâmica imprime valores e normas morais por vezes distintos da cultura ocidental. Tema deste texto, os documentos de direitos humanos do mundo muçulmano divergem, em aspectos significantes, do que defende a Declaração de 1948 da ONU. 0 presente artigo propõe, nesse sentido, tratar dos documentos islâmicos de direitos humanos produzidos em ambiente intergovernamental, dando destaque a dois temas: a liberdade de religião e a liberdade de expressão. A saber, dentre os Direitos assumidos pela ONU na Declaração, tem-se:

Artigo 18 : Toda pessoa tem direito à liberdade de pensamento, consciência e religião; este direito inclui a liberdade de mudar de religião ou crença e a liberdade de manifestar essa religião ou crença,

\footnotetext{
${ }^{2}$ Faz-se válido citar que a Arábia Saudita entendeu que a liberdade de mudar de religião, expressa no artigo 18 da Declaração, era incompatível com o que professava a fé islâmica.
} 
pelo ensino, pela prática, pelo culto e pela observância, isolada ou coletivamente, em público ou em particular.

Artigo $19^{\circ}$ : Toda pessoa tem direito à liberdade de opinião e expressão; este direito inclui a liberdade de, sem interferência, ter opiniões e de procurar, receber e transmitir informações e ideias por quaisquer meios e independentemente de fronteiras (ORGANIZAÇ̃̃O DAS NAÇÕES UNIDAS, 1948).

Sendo o objeto deste trabalho ainda pouco estudado no Brasil, este artigo tem a pretensão de contribuir com uma introdução ao tema. 0 objetivo deste breve estudo é, portanto, levantar os princípios constitutivos de tais documentos, seus processos de construção, e alguns pontos de divergência em relação à declaração ocidental no que tange principalmente à liberdade religiosa e de expressão. Ademais, tratar-se-á da ênfase dada nesses documentos sobre a supremacia da xaria ${ }^{3}$ quando em confronto com alguma fonte de direito externa ao Islã, e da falta de legitimidade de alguns artigos da Declaração de 1948 em contextos islâmicos.

\section{DOCUMENTOS DE DIREITOS HUMANOS NO MUNDO MUÇULMANO}

Dentre os documentos sobre direitos humanos produzidos no mundo muçulmano, o presente artigo deter-se-á àqueles gerados nos últimos anos pelos organismos interestatais e pelos organismos não-governamentais. Toma-se para análise a Declaração dos Direitos do Homem no Islã de 1990 (mais conhecida como Declaração do Cairo), a Carta Árabe dos Direitos do Homem de 1994, e a Declaração do Conselho Islâmico da Europa de 1981 (nomeada Declaração Islâmica Universal dos Direitos Humanos); sendo os dois primeiros documentos desenvolvidos por organismos governamentais e interestatais e o último por organismos não-governamentais.

Os documentos produzidos em ambiente intergovernamental refletem as preocupações dos governos de países de tradição muçulmana em se inserirem na

\footnotetext{
${ }^{3}$ A xaria é um complexo de normas costumeiras religiosas e da jurisprudência muçulmana derivada destas normas. É válido dizer ainda que algumas vezes nomes próprios e traduções do árabe são escritos de formas diferentes, como no caso da palavra "Sharia". Neste artigo reserva-se a forma preferida por cada autor e por cada documento quando se trata de citações diretas. Entretanto, no decorrer do texto preferiu-se dar prioridade para as formas tomadas em português por Demant (2008) em sua obra: o autor usa os termos "xaria" e "Maomé", por exemplo.
} 
discussão dos direitos humanos. E, segundo Pace (2005), é significativo que haja um esforço para elaborar documentos e cartas que tratam de direitos humanos no mundo muçulmano a partir da década de 1980:

[...] quando 0 mundo muçulmano se vê sacudido por dois acontecimentos extraordinários: por um lado, a revolução iraniana de 1979 e a sua involução para um regime autocrático que limita as liberdades fundamentais e, pelo outro, a ofensiva de muitos movimentos radicais (da Argélia ao Sudão, do Egito ao Paquistão), que contestam os grupos dirigentes dos respectivos países, acusando-os de subordinação ao antigo modelo colonial do Ocidente e, por conseguinte, reivindicando a necessidade de retornar ao autêntico Islã da Lei corânica, que se deve aplicar integralmente (PACE, 2005, p. $339)$.

A revolução iraniana de 1979 e a conseguinte Constituição da República Islâmica do Irã tiveram um papel importante na defesa e na propagação das perspectivas islâmicas em todo 0 mundo muçulmano. A experiência de ocidentalização do país marcada por corrupção e inflação durante 0 governo da família Pahlevi, e a forte figura do aiatolá Khomeini contribuíram para a imagem do Irã como nova liderança no mundo islâmico. A transição do Estado iraniano de monarquia autocrática pró-Ocidente para uma República Islâmica, fundada sob os preceitos do Alcorão, fortaleceu a religião e deu fôlego aos movimentos de "islamização" de alguns países; nesse ínterim o discurso de demonização do ocidente na retórica do líder Khomeini ganhou destaque. Nesse sentido, toda essa mobilização para se pensar os direitos humanos em contexto islâmico é, em alguma medida, reflexo desses eventos históricos marcantes no Oriente Médio. Mais que isso:

Sob a pressão desses movimentos, nos ambientes mais laicizados e moderados do mundo muçulmano moderno vai ganhando terreno a convicção de que o confronto com o paradigma dos direitos humanos, assim como estão delineados nos principais documentos da ONU, poderia ser útil para mostrar como a cultura muçulmana não é apenas indiferente à questão dos direitos mas, ao contrário, pode até entrar em sintonia com a moderna cultura dos direitos (PACE, 2005, p. 340). 
0 primeiro documento data de 1981. A Declaração Islâmica Universal dos Direitos Humanos foi aprovada pelo Conselho Islâmico da Europa, em Londres. Preparado por uma organização não governamental denominada Direitos Humanos Islâmicos, tal conselho reunira estudiosos, juristas e representantes muçulmanos de movimentos e pensamentos islâmicos: por isso, apesar do esforço em direção aos direitos humanos, tal documento não tem validade legal para os Estados. Acerca da Declaração Islâmica Universal dos Direitos Humanos, vale ressaltar que, como enfatiza o prefácio, tem como base 0 Alcorão e a Sunna $a^{4}$ :

Há quatorze séculos atrás, o Islã concedeu à humanidade um código ideal de direitos humanos. Esses direitos têm por objetivo conferir honra e dignidade à humanidade, eliminando a exploração, a opressão e a injustiça. Os direitos humanos no Islã estão firmemente enraizados na crença de que Deus, e somente Ele é o Legislador e a Fonte de todos os direitos humanos. Em razão de sua origem divina, nenhum governante, governo, assembleia ou autoridade pode reduzir ou violar, sob qualquer hipótese, os direitos humanos conferidos por Deus, assim como não podem ser cedidos (DECLARAÇÃ̃..., 1981).

A supremacia do que foi pregado e dito pelo Profeta Maomé aparece, pois, como norteadora do documento. São dispostos, ainda no texto introdutório, os fundamentos ético-morais a partir dos quais a declaração foi escrita. Dentre eles, a crença em Deus como único guia da humanidade e fonte de todas as leis, a responsabilidade do homem em satisfazer a vontade de Deus na terra, a orientação da mensagem divina final trazida pelo profeta Maomé, e o acordo com Deus de que os deveres têm prioridade sobre os direitos.

No documento em questão, a referência à xaria aparece nas notas explicativas: "O termo "Lei" significa a Chari'ah, ou seja, a totalidade de suas normas provém do Alcorão e da Sunnah e de quaisquer outras leis que tenham sido baseadas nessas duas fontes, através de métodos considerados válidos pela jurisprudência islâmica." (DECLARAÇÃO..., 1981).

\footnotetext{
${ }^{4}$ Para melhor entender o que é sunna, vale ressaltar que o núcleo normativo islâmico origina-se de uma pluralidade de fontes: o Alcorão, os Ditos e os Atos do Profeta; além das interpretações que interligam mensagens proféticas a preceitos reguladores $\mathrm{da}$ vida social. Tem-se que 0 desenvolvimento político, social e religioso da comunidade religiosa (umma) após a morte de Maomé desafiou os muçulmanos a problemas que não tinham sido solucionados ou expostos no Alcorão. Disso surge o interesse pelo comportamento de Maomé: a chamada sunna do Profeta.
} 
Embora isso seja ressaltado, o conteúdo dos artigos se distingue bastante do que prega a lei corânica no que toca à liberdade de expressão e à liberdade religiosa, visto que apostasia é considerada crime de acordo com leis islâmicas e que blasfêmia é normalmente um tema caro à jurisprudência muçulmana. A ver:

XIII - Direito à Liberdade de Religião: Toda a pessoa tem o direito à liberdade de consciência e de culto, de acordo com suas crenças religiosas.

XII - Direito de Liberdade de Crença, Pensamento e Expressão: Toda a pessoa tem 0 direito de expressar seus pensamentos e crenças desde que permaneça dentro dos limites estabelecidos pela Lei. Ninguém, no entanto, terá autorização para disseminar a discórdia ou circular notícias que afrontem a decência pública ou entregar-se à calúnia ou lançar a difamação sobre outras pessoas. [...] Ninguém será desprezado ou ridicularizado em razão de suas crenças religiosas ou sofrerá qualquer hostilidade pública; todos os muçulmanos são obrigados a respeitar os sentimentos religiosos das pessoas (DECLARAÇÃO..., 1981).

Percebe-se, portanto, uma forte influência da Declaração da ONU, que defende a liberdade de crença e de expressão, sobre este documento. Já no documento seguinte, a Declaração do Cairo de 1990, os temas em destaque recebem um tratamento diferente.

A Declaração do Cairo sobre Direitos Humanos no Islã, datada de 5 de agosto de 1990 foi assinada pela Organização da Conferência Islâmica5 (OCI), após mais de uma década de elaboração. Criada em setembro de 1969, consta em sua Carta de Constituição que a Organização de Cooperação Islâmica ${ }^{6}$ é guiada pelos

\footnotetext{
5 A OCI, em 1969 contava com os seguintes Estados membros: Jordânia, Afeganistão, Indonésia, Irã, Paquistão, Turquia, Chade, Tunísia, Argélia, Arábia Saudita, Senegal, Sudão, Somália, Guiné, Palestina, Kwait, Líbano, Líbia, Mali, Malásia, Egito, Marrocos, Mauritânia, Níger, Iêmen. Atualmente são 57 Estados que aos já citados se somam: Azerbaijão, Albânia, Emirados Árabes Unidos, Uzbequistão, Uganda, Barein, Brunei, Bangladesh, Benin, Burkina Faso, Tadjiquistão, Turcomenistão, República do Togo, Djibuti, Síria, Suriname, Serra Leoa, Iraque, Omã, Gabão, Gâmbia, Guiana, Guiné-Bissau, Comores, Quirguistão, Catar, Cazaquistão, Camarões, Costa do Marfim, Maldivas, Moçambique, Nigéria.

${ }^{6}$ A mesma Organização é referida como Organização de Cooperação e Organização da Conferência Islâmica. No endereço eletrônico da OCI encontra-se a Carta/Legislação de sua constituição, esta, com data de publicação de 2008. Há uma nota final de ratificações no artigo 39 que diz que a
} 
valores islâmicos de unidade e de fraternidade. Estes, tidos como fundamentais para a promoção e 0 reforço da unidade e da solidariedade entre os Estados Membros, uma vez que a proposta da Organização é garantir seus interesses comuns sobre a cena internacional. A carta reafirma o compromisso com os princípios da Carta das Nações Unidas e apresenta como objetivos, dentre outros, propagar, promover e preservar os ensinamentos e valores islâmicos fundados sobre a moderação e a tolerância; promover a cultura islâmica e salvar a herança islâmica; proteger e defender a verdadeira imagem do Islã na luta contra a difamação do Islã; promover e proteger os direitos humanos e liberdades fundamentais, e incentivar o diálogo entre as civilizações e religiões ${ }^{7}$.

Foi na XIX Conferência Islâmica dos Ministros dos Negócios Estrangeiros (Sessão da Paz, Interdependência e Desenvolvimento), realizada no Egito em 1990 que a Declaração do Cairo foi preparada e formalmente adotada pelos Ministros do Exterior da OCI. Por reunir a maioria dos Estados de tradição muçulmana, tal reunião representa a síntese de orientações jurídicas que cada Estado se compromete a seguir sem comprometer a soberania nacional de cada um deles.

A Carta da Organização de Cooperação Islâmica solicitou ainda a criação de uma Comissão Independente Permanente para promover os instrumentos de direitos humanos internacionalmente reconhecidos. A OCI atendeu tal solicitação e publicou um documento intitulado "Regulamento Interno da Comissão Permanente de Direitos Humanos da OCI" com os procedimentos para a realização de sessões da Comissão, assim como para o exercício de suas funções. Já o Estatuto da Comissão Permanente de Direitos Humanos data de junho de 2010. A iniciativa da Organização de Cooperação Islâmica em criar uma Comissão de Direitos Humanos, reafirmando a Declaração do Cairo de 1990 e ao mesmo tempo assegurando a cooperação com organizações internacionais como a Organização das Nações Unidas, faz crer que, assim como assinalou Pace (2005), apesar de não se caracterizar como um tratado internacional que vincule os países signatários, a Declaração do Cairo continua sendo até hoje a mais articulada carta de direitos humanos assumidos do ponto de vista dos Estados de tradição muçulmana.

A Declaração do Cairo conta com 25 artigos e é precedida de um amplo preâmbulo que enfatiza seu caráter islâmico e seu embasamento de acordo com a xaria. Destaca-se:

presente Carta substitui a Carta da Organização da Conferência Islâmica registrado em $1^{\circ}$ de fevereiro de 1974, o que comprova que se trata da mesma Organização.

${ }^{7}$ A Carta está disponível em: http://www.oic-oci.org/french/charter/OIC\%20charter-new-fr.pdf. 
[...] Acreditando que os direitos e liberdades fundamentais de acordo com o Islã são parte integrante da religião islâmica e que ninguém tem o direito como uma questão de princípio, para extingui-los, no todo ou em parte ou violar ou ignorá-los, na medida em que mandamentos divinos são vinculativos, que estão contidos nos Livros Revelados de Deus e que foram enviadas através do último dos seus profetas para completar a mensagem divina anterior e que a salvaguarda desses direitos e liberdades fundamentais é um ato de adoração ao passo que a negligência ou violação da mesma é um pecado abominável, e que a salvaguarda dos direitos fundamentais e a liberdade é uma responsabilidade individual de cada pessoa e uma responsabilidade coletiva de toda a Ummah [...] (NINETEENTH ISLAMIC CONFERENCE OF FOREIGN MINISTERS, 1990, tradução nossa).

Encontra-se já no texto inicial que os direitos humanos como parte integrante da religião muçulmana devem conservar o que está posto no Alcorão e na tradição do Profeta, sendo essas as fontes de lei maior e às quais o indivíduo deve obediência, como ressalta 0 trecho. 0 conteúdo dos artigos da Declaração de 1990 deixa claro tanto a subordinação a Deus, como a superioridade da Lei corânica (xaria) como guia de todo o sistema de direitos. 0 segundo artigo afirma, nesse sentido:

[...] é proibido tirar a vida, exceto por uma razão na Shari'ah prescrita. [...] A segurança do dano corporal é um direito garantido. É dever do Estado protegê-lo, e é proibida a violação sem uma razão na Shari'ah prescrita (NINETEENTH ISLAMIC CONFERENCE OF FOREIGN MINISTERS, 1990, tradução nossa).

Pensando os direitos de liberdade de expressão, tema caro ao mundo muçulmano com relação ao Ocidente, como os emblemáticos casos de protestos islâmicos ligados à acusação de blasfêmia ${ }^{8}$, vale citar:

Artigo $16^{\circ}$ : Todos têm o direito de gozar os frutos do seu domínio científico, de trabalho, literária, artística ou técnica da qual ele é 0

\footnotetext{
${ }^{8}$ Se cabe citar exemplos, a condenação de morte emitida por Khomeini em 1989 ao autor Salman Rushdie e as ondas de protesto contra a publicação das charges do Profeta Maomé em 2006 na Dinamarca.
} 
autor, e ele terá o direito à proteção dos seus interesses morais e materiais que daí decorrem, desde que não seja contrária aos princípios da Sharia [...].

Artigo $22^{\circ}$ : (A) Toda pessoa terá o direito de expressar sua opinião livremente da forma que não seria contrário aos princípios da Sharia (NINETEENTH ISLAMIC CONFERENCE OF FOREIGN MINISTERS, 1990, traduçãa nossa).

Quanto à liberdade de religião, de fato uma questão de suma importância na tradição islâmica, 0 artigo 18 da referida declaração deixa claro 0 respeito às minorias religiosas afirmando que toda pessoa terá 0 direito de viver em segurança com sua religião, seus dependentes, sua honra e sua propriedade. Já 0 artigo que trata da religião islâmica faz objeção à mudança de credo: "Artigo $10^{\circ}$ : 0 Islã é a religião da natureza intocada. É proibido exercer qualquer forma de coerção sobre o homem ou explorar a sua pobreza ou ignorância, a fim de convertê-lo para outra religião ou ao ateísmo". Ademais, a formação na fé islâmica também é citada pelo documento no artigo que trata sobre direito à educação:

Artigo $9^{\circ}$ : 0 Estado deve assegurar a disponibilidade de meios e formas de aquisição da educação e garantir a diversidade educativa, no interesse da sociedade, de modo a permitir que os homens se familiarizarem com a religião do Islã e os fatos do Universo, em benefício da humanidade (NINETEENTH ISLAMIC CONFERENCE OF FOREIGN MINISTERS, 1990, tradução nossa).

Ao contrário do que se encontra na Declaração de 1981 sobre liberdade religiosa, a Declaração do Cairo não defende a liberdade de crença aos muçulmanos. A Declaração do Cairo afirma, em consonância com preceitos islâmicos, que o Islã é a religião natural do ser humano e, por isso, torna-se proibido mudar de religião ou assumir-se ateu, defendendo também a formação religiosa como direito.

Acerca da supremacia da xaria, os dois últimos artigos da declaração não deixam dúvidas:

ARTIGO 24: Todos os direitos e liberdades previstos na presente Declaração estão sujeitos a Sharia islâmica. 
ARTIGO 25: A Sharia islâmica é a única fonte de referência para a explicação ou esclarecimento de qualquer um dos artigos da presente Declaração (NINETEENTH ISLAMIC CONFERENCE OF FOREIGN MINISTERS, 1990, tradução nossa).

0 terceiro e último documento a ser abordado é a Carta Árabe dos Direitos Humanos aprovada em 15 de setembro de 1994. Esta, por sua vez, é um autêntico tratado intergovernamental submetido à ratificação dos Estados. A Carta foi elaborada pelos governos dos Estados-membros da Liga dos Estados Árabes ${ }^{9} \mathrm{e}$ afirma se basear na tradição árabe para encontrar afinidades eletivas com 0 paradigma dos direitos humanos: o que a distingue dos outros documentos que se fundamentam nas fontes religiosas do Islã.

No preâmbulo da Carta Árabe consta:

Reafirmando os princípios da Carta das Nações Unidas e a Declaração Universal dos Direitos Humanos, bem como as disposições das Nações Unidas Pactos Internacionais sobre Direitos Civis e Políticos e Econômicos, Sociais e Culturais e a Declaração do Cairo sobre Direitos Humanos no Islã [...] (COUNCIL OF THE LEAGUE OF ARAB STATES, 1994, tradução nossa).

Um projeto complicado, visto que a Declaração do Cairo e a Declaração de Direitos Humanos da ONU têm divergências, como as que foram citadas.

A Carta Árabe, composta por 43 artigos, garante a liberdade religiosa e de culto e se aproxima, de maneira geral do documento de 1948:

Artigo $26^{\circ}$ : Toda a pessoa tem um direito garantido à liberdade de pensamento crença e de opinião.

Artigo $27^{\circ}$ : Os adeptos de cada religião têm o direito de praticar seus rituais religiosos e de manifestar suas opiniões através da expressão, prática ou de ensino, sem prejuízo dos direitos dos outros. Nenhuma

\footnotetext{
${ }^{9}$ Fundada em 1945, os 22 Estados-membros da Liga dos Estados Árabes e que assinaram a Carta Árabe dos Direitos Humanos são: Jordânia, Emirados Árabes Unidos, Bahrain, Tunísia, Argélia, Djibuti, Arábia Saudita, Sudão, República Árabe da Síria, Somália, Iraque, Omã, Palestina, Catar, Comores, Kuwait, Líbano, Líbia, Egito, Marrocos, Mauritânia, Iêmen.
} 
restrição deve ser imposta ao exercício da liberdade de pensamento, crença e opinião, exceto nos casos previstos em lei (COUNCIL OF THE LEAGUE OF ARAB STATES, 1994).

Tem-se, portanto, que os direitos humanos na leitura da cultura árabe, como proposto pela Carta, não apresentam significativas distinções sobre os direitos declarados pela ONU. No entanto, apesar de ser 0 último documento de direitos humanos a ser assinado e de sua característica de tratado intergovernamental, a Carta Árabe não encerra a discussão sobre algumas questões, como da liberdade religiosa e de expressão, por exemplo. Uma vez que a lei corânica é tida como a primeira lei do Islã, a supremacia da xaria torna-se um ponto-chave nesses debates.

\section{XARIA: BREVES CONSIDERAÇÕES SOBRE A SUPREMACIA E AS POSSIBILIDADES INTERPRETATIVAS}

Pace (2005) enfatiza que a relação entre Islã e direitos humanos remete à relação entre o Islã e a democratização de países em que há um nexo entre religião e política. De acordo com a abordagem desse autor, se os direitos humanos entram em choque com a Lei corânica (xaria), a última deve prevalecer. Esse é o principal obstáculo a uma completa adesão do Islã à moderna cultura dos direitos humanos, observa.

Nesse sentido, vale ressaltar que o núcleo normativo origina-se de uma pluralidade de fontes: o Alcorão, os Ditos e os Atos do Profeta; além das interpretações que interligam mensagens proféticas a preceitos reguladores $\mathrm{da}$ vida social. Tem-se que o desenvolvimento político, social e religioso da comunidade religiosa (umma) após a morte de Maomé desafiou os muçulmanos a problemas que não tinham sido solucionados ou expostos no Alcorão. Disso surge o interesse pelo comportamento de Maomé (a chamada sunna do Profeta) e por suas palavras, ditas quando não proclamava o Alcorão (afirmações que são conhecidas como hadith). Dessa forma, a sunna e o hadith (que se sobrepõem) se impuseram como fontes adicionais do direito islâmico ao lado do Alcorão.

Como a comunidade fundada sobre os princípios da Lei de Deus (a xaria) não necessitava de sacerdotes mediadores entre os crentes e Deus, após a morte do Profeta os peritos da religião e da política tornaram-se responsáveis também pela interpretação da Lei (atividade esta que se tornou fonte de controvérsias). Tendo em vista que o Alcorão traz princípios reguladores da vida social e política 
da comunidade então estabelecida, a interpretação da lei islâmica, tanto do Alcorão como da coleção dos fatos e ditos atribuídos ao Profeta, produziu e ainda hoje produz uma considerável diversidade de opiniões (ANTES, 2003). Sobre 0 esforço racional de interpretação,

Em suma, além das fontes reveladas, as normas sobre 0 estatuto pessoal foram sucessivamente elaboradas em termos de interpretação racional à luz da fé, realizada por eruditos em assuntos religiosos ('ulama), legisladores (fuqaha) e juízes das cortes (qadi). Tudo isso tendo como pano de fundo uma subordinação orgânica dessas figuras do saber religioso à autoridade política dos califas dos grandes impérios muçulmanos do passado (PACE, 2005, p. 321).

A concepção do núcleo normativo contava, portanto, com uma metodologia de pensamento e interpretação (fiqh), e o produto final ficou conhecido como xaria. A supremacia da xaria se deve, desse modo, à referência a uma norma fundamental que se considera revelada por Deus, segundo a qual os direitos humanos não têm fundamento fora ou contra os direitos divinos, sobretudo porque há a ideia de que todo ser humano, de acordo com o pensamento teológico muçulmano, nasce disposto naturalmente ao Islã.

A isso se remete uma das violações mais evidentes da cultura muçulmana que entra diretamente em choque com o sistema de direitos humanos: a liberdade de mudar de religião. Compreendido como um mal abominável e que deve ser perseguido, o abandono da religião em que se nasceu (no caso do Islã) significa tanto um ato de rejeição da verdade divina, como de insubordinação contra 0 poder constituído na sociedade. Dentre outras questões que entram em choque com os direitos humanos, o modo como as minorias não muçulmanas são tratadas em alguns países de maioria islâmica, e a relação de desigualdade entre homens e mulheres se destacam. Questões como essas são também objeto de confronto interno e de movimentos sociais no mundo muçulmano e, assim como para a discussão intergovernamental de direitos humanos, representam um grande desafio, uma vez que dizem respeito ao campo da política e da religião.

Pode-se afirmar, entretanto, que tendo em vista o processo de interpretação das fontes normativas do Islã, a lei islâmica pode não ser uma lei de todo imutável e incompatível com o paradigma dos direitos humanos. Nesse sentido, para Pace, a xaria: 
[...] não é certamente um edifício compacto e coerente, cujas paredes estão fora de dúvida assentadas sobre as duas fontes principais, do Alcorão de um lado e da coletânea dos Ditos e Atos do Profeta (a tradição oral, transcrita e transmitida por uma cadeia de fiéis transmissores e testemunhas), do outro lado, mas às vezes pontilhadas pelo direito consuetudinário e pelos usos locais que no decurso da sua expansão, entre os séculos VII e IX, o Islã ia encontrando e não conseguia suprimir [...] Além disso, justamente porque o problema fundamental que os primeiros Estados imperiais muçulmanos tiveram de encarar era a distância entre tudo o que se achava contido nas fontes sagradas acima mencionadas e a realidade social e política que ia se tornando mais complexa e diferente da pequena comunidade originária nos tempos do Profeta, por mais de dois séculos se havia dado um amplo espaço ao trabalho interpretativo de peritos em questões religiosas. Estes, muitas vezes, tiveram de recorrer ao raciocínio analógico ou a uma verdadeira hermenêutica dos textos sagrados para encontrar amparo visando a definição de novas regras jurídicas e sociais (PACE, 2005, p. 329-330).

Importa ainda destacar que a xaria, embora seja reivindicada como universal, tem sua aplicação amplamente variada nos países de maioria muçulmana, ou seja, não se caracteriza como código fixo aplicado igualmente nos diversos contextos sociais (o que se aproxima muito dos procedimentos da Commor Law, por exemplo). E, nesse contexto, vale ressaltar também que xiitas e sunitas divergem sobre alguns pontos interpretativos da lei corânica. Nesse sentido, os processos de interpretação da lei corânica e as diferentes leituras quanto à aplicabilidade da xaria permitem, de alguma maneira, o desenvolvimento do projeto de internacionalização dos direitos humanos sem anular, todavia, as diversidades culturais.

\section{LEGITIMIDADE EM QUESTÃO}

Ao tratar da relação entre o Islã e os direitos humanos, Pace (2005, p. 323) afirma que "[...] a dificuldade maior que o Islã encontra na recepção cabal do paradigma dos direitos humanos, da maneira como se consolidaram no seio da ONU, é estrutural porque se refere ao problema não resolvido da falta do princípio de legitimação da autoridade". E segue: "Pode parecer paradoxal, mas no Islã, [...] a crença no fim do ciclo da profecia com Muhammad tem consequências 
inesperadas: nenhuma pessoa, depois do Profeta, tem o poder de interpretar a revelação originária” (PACE, 2005, p. 323-324).

Somado à variedade das fontes do núcleo normativo de países de maioria muçulmana e à possibilidade de uma diversidade de interpretações, Pace destaca a questão estrutural da legitimidade de direitos no Islã. Segundo 0 autor, "Entre 0 Islã e a política se interpõe o direito no Islã [...]" (PACE, 2005, p. 324), mas quando se fala de déficit estrutural de legitimação no Islã como desafio à adesão ao sistema de direitos humanos, refere-se às características originárias, particularmente à fusão entre as dimensões religiosa e política. Quanto às normas jurídicas, vale ressaltar que é a motivação ético-religiosa que as inspira; assim, qualquer sistema de lei acaba sendo um projeto submetido a contínuas tensões interpretativas.

Dada a junção das funções de liderança espiritual e política durante a vida do Profeta Maomé "[...] o Islã insiste na unidade de ambos pela fórmula din-wadawla (religião e Estado) e com isso recusa uma sociedade secular [...]" (ANTES, 2003, p. 123); o que desde a morte do Profeta constitui problemas muito específicos de secularização devido à forte inter-relação entre religião e política que se deu nos tempos em que viveu. 0 que, como aborda Pace, é uma questão de carisma ${ }^{10}$ :

Em virtude do seu carisma espiritual, este acabou exercendo a dupla função de reformador religioso, sobretudo na primeira fase da sua pregação em Meca e, em seguida, de líder político, na cidade de Medina. A legitimidade no comando tinha sua fonte na autoridade carismática do Profeta. [...] religião e política não podiam ser separadas, porque o carisma é pessoal, a graça extraordinária recebida por Muhammad com a revelação era indivisível, por definição (PACE, 2005, p. 325).

E, como nos faz lembrar Weber (1991, p.141), no caso da dominação carismática "[...] obedece-se ao líder carismaticamente qualificado como tal, em virtude de confiança pessoal em revelação, heroísmo ou exemplaridade dentro do âmbito da crença nesse seu carisma". Nesse sentido, a base da ideia weberiana de

\footnotetext{
${ }^{10}$ Weber (1991) denomina "carisma" a qualidade insólita de uma pessoa que parece dar provas de um poder sobrenatural, sobre-humano ou pelo menos desusado, de sorte que ela aparece como um ser providencial, exemplar, ou fora do comum e, por essa razão, agrupa em torno de si discípulos ou partidários.
} 
legitimidade relacionada à crença, seja no carisma do líder, seja no domínio tradicional, se distingue da legitimidade jurídica ocidental que opera a partir da separação entre direito e moral. A questão é que para o Islã, e como visto em alguns documentos de direitos humanos, a lei islâmica é tanto fundamento de leis morais, como uma referência jurídica. A conexão entre política, direito e religião no Islã tem pesos diferentes para cada um dos países de maioria islâmica, assim como dentro da heterogênea sociedade muçulmana, mas não é um peso que pode ser ignorado.

Habermas discute a introdução de liberdades subjetivas ao tratar do direito moderno e comenta a separação entre direito e moral: 0 direito moderno diferencia-se das ordens jurídicas tradicionais justamente pelo fato de separar direito de moral. Para o autor, "Enquanto os direitos morais são derivados de obrigações recíprocas, as obrigações jurídicas o são da delimitação legal das liberdades subjetivas" (HABERMAS 2001, p. 144-145). Nesse sentido, a legitimidade dos direitos humanos firmados nas Nações Unidas é pensada no contexto do Estado moderno, ou seja, em termos weberianos, do Estado racional legal. Portanto, sua legitimidade está ligada à relação entre secularidade e direitos do homem: requisito da constituição de uma sociedade moderna de direito onde há a autonomia das esferas, e que em tese garante igualdade e liberdade a todos os indivíduos.

Trata-se, pois, de formas de legitimidades distintas, frutos de histórias e de culturas demarcadas. Diante disso, levanta-se o debate sobre a pretensão de universalidade dos direitos humanos. Cabe mencionar, nesse sentido, duas abordagens, mesmo que brevemente. Para Habermas (2001), os direitos humanos são legítimos como código de validade universal nas questões interculturais, de modo que a legitimação desse sistema de direitos como linguagem e instrumento no cenário internacional abre uma oportunidade de diálogo e reflexões a fim de esclarecer os "pontos cegos" supostamente existentes na declaração de 1948. Diante de argumentações de que o talhe individualista e secular, assim como as fundamentações do direito moderno tornam os direitos humanos um código de validade universal, Habermas defende o direito moderno e, por consequência, os direitos humanos como instrumentos válidos para 0 processo de democratização. Para ele, um processo de democratização sob a diretriz do discurso racional possibilita o reconhecimento mútuo das culturas e a coexistência dessas em um sistema de tolerância e de igualdade de direitos.

Já para Said (1990), que toma o orientalismo como um fato político e cultural, o Oriente é dado não só pela sua localização geográfica e pela sua 
diferenciação cultural, como também pela concepção do "outro" que adquiriu na construção político-ideológica do Ocidente. Segundo o autor, no trato com temas do Oriente, e consequentemente do mundo muçulmano, há uma ênfase nas distinções entre o que é "nosso" e o que é "deles" (quanto à concepção de mundo, por exemplo) sempre em uma designação avaliativa. Tal interpretação muitas vezes corresponde à ação de se conceber o "deles" de acordo com o ponto de vista e em função do que é "nosso". Nesse aspecto, a subordinação histórica de linguagem e de códigos ao trato ocidental precisa ser considerada para que se evite as padronizações culturais quando se aborda questões do mundo muçulmano. 0 autor adverte, portanto, sobre o risco de ações de dominação política e cultural ao se tentar minimizar as diferenças entre tais sociedades.

\section{CONSIDERAÇÕES FINAIS}

Pode-se afirmar, a partir do que foi exposto, que a relação entre direitos humanos e Islã não está fadada à incomunicabilidade, assim como não está determinada a uma supressão das diversidades culturais. Percebeu-se que há divergências entre os fundamentos ético-morais das duas ordens (a moderna e a islâmica) os quais se expressam, inevitavelmente, nos diferentes documentos de direitos humanos.

Se por um lado o fator complicador da validade dos direitos humanos como declarados em 1948 pela Organização das Nações Unidas em contextos de tradição muçulmana é de cunho estrutural, por outro, é importante notar que há um esforço para assimilar o paradigma dos direitos humanos em muitos dos países de tradição muçulmana: o que acrescenta positivamente ao debate sobre a necessidade de garantia de direitos aos seres humanos do mundo inteiro..

São muitos os estudiosos que se debruçam sobre o tema deste artigo, tanto no ocidente como em países islâmicos. Há uma vasta literatura em que os direitos humanos no mundo muçulmano são objetos de pensamento, assim como há muitos trabalhos que problematizam a pretensão universal da Declaração da ONU. Vale ressaltar que não era a proposta deste texto dar conta desses debates, mas tão somente tratar desses documentos e de alguns pontos-chave que eles apresentam, como dito. 


\section{REFERÊNCIAS}

ANTES, Peter. O Islã e a política. São Paulo: Paulinas, 2003.

COUNCIL OF THE LEAGUE OF ARAB STATES. Arab charter on human rights. 1994. Disponível em: <http://ww.albab.com/arab/docs/international/hr1994.htm > . Acesso em: 25 fev. 2011.

DECLARAÇÃO islâmica universal dos direitos bumanos. Traduzido por Mônica Muniz e Maria Moreira. 1981. Disponível em: $<$ http://www.dhnet.org.br/direitos/anthist/ declaracaoislamica.html $>$. Acesso em: 25 fev. 2011.

DEMANT, Peter. O mundo muçulmano. São Paulo: Contexto, 2008.

HABERMAS, Jürgen. A constelação pós-nacional: ensaios políticos. São Paulo: Littera Mundi, 2001.

NINETEENTH ISLAMIC CONFERENCE OF FOREIGN MINISTERS. Cairo Declaration on Human Rights in Islam. 1990. Disponível em: <http://wwwl.umn.edu/humanrts/instree/cairodeclaration.html $>$. Acesso em: 25 fev. 2011.

ORGANIZAÇÃO DAS NAÇÕES UNIDAS. Declaração Universal dos Direitos Humanos. 1948. Disponível em: <http://portal.mj.gov.br/sedh/ct/ legis_intern/ddh_bib_inter_universal.htm > . Acesso em: 20 jan. 2011.

ORGANIZAÇÃO DE COOPERAÇÃO ISLÂMICA. Carta da Organização de Cooperação Islâmica. Disponível em: <http://www.oicoci.org/french/charter/OIC\%20charter-new-fr.pdf> . Acesso em: 5 set. 2013.

PACE, Enzo. Sociologia do Islã: fenômenos religiosos e lógicas sociais. Petrópolis: Vozes, 2005.

SAID, Edward W. Orientalismo: o oriente como invenção do ocidente. São Paulo: Companhia das Letras, 1990.

TRINDADE, Antonio Augusto Cançado. Tratado de direito internacional dos direitos humanos. Porto Alegre: Sergio Antonio Fabris Editor, 2003. v. 3.

WEBER, Max. A psicologia social das religiões mundiais. In: .Ensaios de sociologia. Rio de Janeiro: Zahar, 1946. p. 307-335.

WEBER, Max. Economia e sociedade: fundamentos da sociologia compreensiva. Brasília: Editora Universidade de Brasília, 1991. 